\title{
FINLAND'S RAPPROCHEMENT TO NATIONAL-SOCIALIST GERMANY AS REACTION AGAINST WINTER WAR
}

\section{Kalervo Hovi}

University of Turku, E-Mail: kalervo.hovi@gmail.com

\section{Acknowledgments}

This paper has been presented at the Fourth international conference on Baltic and Nordic Studies in Romania Empire-building and Region-building in the Baltic, North and Black sea areas hosted by the Romanian Association for Baltic and Nordic Studies and Ovidius University of Constanta, May 24-26, 2013.

\begin{abstract}
:
The aim of this article is to analyse the reasons behind the Finnish co-belligerency with Germany in the Operation Barbarossa. The investigation reveals the main reasons and key moments which contributed to Finnish rapprochement with Nazi Germany following the Winter War when their relations reached the nadir. Therefore, the article looks at the attitude of Finnish, German and Soviet decisionmakers following the Winter War and sets the Finnish decision within the frame of Finnish national interest as defined by its elites and not in an ideological choice of Totalitarian doctrine of National-Socialism. Ironically, after cooperating in the war against Soviet Union, Finland and Germany became open enemies after the Finnish armistice with Soviet Union was concluded.
\end{abstract}

\section{Rezumat:}

Scopul acestui articol este acela de a analiza rațiunile care explică cobeligeranța Finlandei cu Germania în cadrul Operațiunii Barbarossa. Investigația relevă principalele rațiuni și momentele cheie care au contribuit la apropierea Finlandei de Germania Nazistă după ce în timpul Războiului de Iarnă relațiile dintre cele două state ajunseseră la nadir. Prin urmare, articolul dezvăluie atitudinea factorilor de decizie finlandezi, germani și sovietici după încheierea Războiului Rece și plasează decizia finlandeză în cadrul interesului național finlandez așa cum a fost acesta definit de elitele finlandeze și nu ca pe o alegere ideologică în favoarea doctrinei totalitare a național-socialismului. Este paradoxal faptul că după ce au colaborat în războiul împotriva Uniunii Sovietice, Finlanda și Germania au devenit state inamice în urma semnării armistițiului dintre Helsinki și Moscova. 
Keywords: Finland; Germany; Soviet Union; Winter War; Continuation War; Operation Barbarossa

7 he relations between Germany and Finland have been fairly good for centuries. Trade connections have been lively and highly profitable for Finns. Since the 15th century the universities of Northern Germany provided the highest education available. The reformation spread from Germany, and the Finnish reformer Mikael Agricola was Melanchton's student in Wittenberg. The Reichsregierung supported the Finnish independence with advice and armed support in 1917-1918. So Germany, be it Imperial Germany, the Republic of Weimar or National-Socialist Germany, was Germany, above all, for most Finns.

The political pressure of the dictatorial powers against small states began to be felt as soon as 1937, but the Hitler-Stalin-Pact of August 1939 constituted a real shock. One had thought that the Nazi-Soviet antagonism is an axiom, and the Finns felt it particularly important that Germany could remain as a counterweight against the Soviet Union. The nations of the area could not expect anything good from the pact, but the division of the spheres of interest was fatal. The results were soon to be seen. Poland was attacked and divided by Germany and the Soviet Union. At the same time, the Soviet Government started to demand cessions of territory and military bases from her Western neighbours.

The Soviets demanded frontier rectifications from Finland, too. Above all, the Finnish frontier on the Karelian Isthmus ought to be drawn some $70 \mathrm{~km}$ westwards. Furthermore, the Russians required a naval base on the Western Coast of Finland and a pact of mutual assistance. The Baltic States had consented to similar demands. Marshal Mannerheim and the former Ministerpresident and future President of the Republic J.K. Paasikivi, who knew Russia well, recommended concessions, but the Finnish Government did not want to give in straight away. The pact of mutual assistance and the military base were out of the question, and on the Karelian Isthmus they did not want to yield much of the ancient Finnish soil. The Finnish delegation, led by Paasikivi travelled three times to Moscow in order to negotiate. The gap between the latest Russian demands and Finnish concession was only $20 \mathrm{~km}$ of land, but the demands for a naval base in the West and above all the pact of mutual assistance were seen as incompatible with the Finnish independence. At this phase, the Russian Government 
broke off the negotiations, denounced the treaty of non-aggression and started a war against Finland on November 30th, $1939 .{ }^{1}$

So Russia, whose Government until this day claims that they have never started a war, nevertheless attacked. The first attack was a political one. A puppet government was established under Finnish exile in Moscow, communist O.V. Kuusinen. He accepted all Russian demands. The endeavour was masked on the 1st of December as a Finnish people's government, pretending to assemble at the Karelian Parish Terijoki. On that day, Terijoki was still in the hands of Finnish covering forces. ${ }^{2}$

After the outbreak of the war, Germany practised a strict but proSoviet neutrality. Hitler is said to have published in the Völkischer Beobachter on the 8th of December an article where he denied all German responsibility for events in the North and blamed the Finns of harbouring a hostile attitude towards the Germans. That was a turn that was horrid, and the Finns employed considerable effort to improve relations with Germany. There were only private expressions of sympathy, official Germany remained chilly. Later on Hitler tried to show regret, and in June 1942 he came to Finland to congratulate Mannerheim on his 75th birthday. ${ }^{3}$ Only Reichsmarschall Göring let some light show through the clouds. He wrote to Marshal Mannerheim at the beginning of November: "Please concede in the discussions with Russia. Germany cannot help at the moment, but afterwards we shall compensate everything."4

The Finnish Government did not trust those vague promises, but decided to defend herself. She was supported by the sympathy wave of the world's public opinion. Furthermore, many states helped Finland with armament and volunteers, above all Sweden and Italy. Even Göring had let "by mistake" some armament come through. When the Russians rigorously watched the behaviour of the Germans, it was agreed that Sweden would supply the Finns with armament from her depots and these would then be

\footnotetext{
1 Jukka Tarkka, Neither Stalin nor Hitler. Finland during the Second World War, transl. by David Mitchel (Helsinki, 1991), 9-12.

2 See Osmo Jussila, Terijoen hallitus 1939-1940 [The Terijoki Gióvernment, 1939-1940] (Helsinki, 1985).

${ }^{3}$ Gerd R. Ueberschär, Hitler und Finnland 1939-1941. Die deutsch-finnischen Beziehungen während des Hitler-Stalin-Paktes (Wiesbaden: Frankfurter Historische Abhandlungen 16, 1978), 111-117. See also Jukka Parrtanen, Manerheim ja Hitler [Mannerhein and Hitler] (Helsinki, 2012).

4 Risto O. Peltovuori, Saksa ja Suomen talvisota [Germany and the Finnish Winter War] (Helsinki 1985), 51-52.
} 
compensated by Germany. ${ }^{5}$ So even the German sins were not as blood-red as they looked.

The Russians first thought that they can cope with Finland with the strengthened forces of the military district of Leningrad, as such more populated than the whole of Finland. This did not succeed. The Finns managed to keep the main defence line in the Karelian Isthmus for over two months, and the attacks in the wide areas in the North were repelled by a moving warfare. Then the Soviet Union took recourse to her whole Great Power army, and at the end of February 1940 the Russians attained a limited breakthrough. ${ }^{6}$

The Finnish Government had to consider the possibilities of peace. Great Britain and France had promised an active support, and this was an alternative. 7 Still new emissaries were sent to Berlin, too, and at the end of February they were suddenly received at the highest level. Göring stressed again that Finland should make peace as soon as possible. It was most important that Finland could remain independent. The war between Germany and the Soviet Union would break out in the nearest future, and the temporary losses could be compensated later on. ${ }^{8}$

The Finnish Government decided to make peace at the end of February. Decisive reasons were that the strength of the Finnish armed forces began to be exhausted. The effective help of the Western Powers was at the end not believed in, but the possibility of Western intervention was probably responsible for the fact that Stalin was ready to let Kuusinen's government fall and make peace with the legal government of Finland. The words of Prime Minister Ryti might have been decisive, too: "We have to make peace with no delay, in order to keep the army capable to fight so that Finland under better conditions will be strong enough. It is better to start the recapture of Karelia from Vyborg (in Karelia) than from Tornio (at the Swedish border). So the decision was made in great lines according to the

\footnotetext{
5 Ibid., 89-70.

${ }^{6}$ Lasse Laaksonen, "Kannaksen taistelut" [Combats on the Karelian Isthmus], Talvisodan pikkujättiläinen [Concise History of the Winter War], eds. Rari Leslien and Antti Juutilainen. (Helsinki 1999), 435-453.

7 Jukka Nevakivi, Appeal that was never Made, Allies, Scandinavia and the Finnish Winter War 1939-1940 (London, 1976).

${ }^{8}$ Heikki Ylikangas, "Saksa ja Suomi talvisodasta välirauhaan" [Germany and Finland from the Winter war to the Interim peace], in Heikki Ylikangas, Tulkintani talvisodasta [My interpretation of the Winter War] (Helsinki, 2000), 182-184.
} 
recommendation of Göring. The peace was signed in Moscow on March 13th, $1940 .{ }^{9}$

The peace conditions were severe. Finland had to give up the entire Karelian Isthmus with Vyborg. Also parts of parishes Kuusamo and Salla as well as Petchenga on the Eastern border had to be given up. Finns had to rent the Cape of Hanko in Western Finland to the Soviet Union for a naval base but the feared pact of mutual assistance could be avoided. Some 23500 Finnish soldiers had died, and 420000 Karelians were resettled in the rest of Finland. The starting of the war by the Russians and the harsh peace terms were felt deeply unjustified in Finland. This kind of peace could only been seen as a truce, as an interim peace. 10

And the peace did not end the political pressure from the side of the Russians. New demands, provocations and crises caused insecurity in the country. The Finns could also watch from the nearest vicinity how the Russians behaved in the Baltic States. In this tense situation the Finns waited for signs of the altered attitude of Germany. When the Germans again offered weapons and asked for permission to pass German furlough soldiers via Finnish territory to Norway in August 1940, the Finnish government immediately consented. ${ }^{11}$ Then the rapprochement proceeded rapidly. In November, Hitler turned away the demands of Soviet Foreign Minister Molotov. Molotov wanted to have free hands to arrange the Finnish affairs like the Soviets had done in the Baltic States, i.e. to occupy the country. ${ }^{12}$ In this phase Germany has raised her umbrella over Finland.

In December it was already obvious that Germany will attack. Mannerheim had sent his trustee General Paavo Talvela to Germany. When Colonel General Franz Halder, Chief of the German General Staff asked how long the mobilization of the Finnish army to the border would take and which was the bearing capacity on the roads of Northern Lapland, the meaning of the questioning was clear for the Finnish general. Germany prepared to attack very soon, and the Finnish Government decided to go on

\footnotetext{
9 Ibid., 193-202.

${ }^{10}$ Martti Turtola, "Katkera rauha ja Suomen ulkopoliittinen asema" [The Bitter Peace and the position of Finnish foreign policy], in Talvisodan pikkujättiäinen [The Concise History of the Winter War], toim/ eds. Jari Leskinen, Antti Juutilainen (Helsinki, 1999).

11 Mauno Jokipii, Jatkosodan synty. Tutkimuksia Saksan ja Suomen sotilaallisesta yhteistyöstä 194041 [Emergence of the Continuation War. Researches of the German and Finnish Military Cooperation 1940-41] (Helsinki 1987).

12 Ibid., 193-119.
} 
with it, in order to reconquer Karelia. General Erik Heinrichs, Chief of the Finnish General Staff, had permission from the Finnish political leadership to reveal the country's operational preparedness and to outline the grouping of its main troops to the Germans at the end of January 1941. A delegation of officers for final discussion was sent to Germany in May ${ }^{13}$. When the war in summer 1941 broke out, Göring was given a very high Finnish distinction as an expression of gratitude for the advice in February 1940. ${ }^{14}$

So the Finnish decision originated in her own national interest. The Finnish government wanted to have back the territory which unjustified and violently had been taken from her a good year earlier. In the circumstances this was possible only with the help of Germany, the only Great Power willing and capable to help in this endeavour. It was no conscious choice in the global struggle between totalitarism and democracy. Finland herself was a relatively well established democracy and the only aggressor against Finland was the Soviet Union which by no means could be held as a democracy and defender of freedom of the peoples. On the other hand the Finns were not blindly German-oriented. In the fight against the devil they were ready to take help even from Beelzebub.

Finnish historiography has not willingly identified Finland with the other allies of Germany. There have been long discussions if Finland was an ally or a co-warrior. Most practical details of the cooperation on the Northern front were negotiated together, but no political pact was ever made. Finland as a co-warrior had also preserved her full right of decision. Despite continuous German demands Mannerheim refused to attack Leningrad or cut off the main line of the Murmansk railway. As a former Russian general he knew that after such fatal decisions there was no way to a reasonable peace. Mannerheim refused to take the German troops in Finland under his command, too. So he did not need to take orders from the German on command matters. Finland was the only state on the German side which protected her Jewish minority. The Jews as equal Finnish citizen were national servicemen, too. So it happened that the Jewish soldiers in Finland fought together with NS-Germany against the Soviets. ${ }^{15}$ This was totally unique. On the other hand there were peculiarities in the policy of the other

\footnotetext{
13 Tarkka, 36-37,

14 Kalervo Hovi, “Göring ja Talvesõda” [Göring and the Finnish Winter War], Tuna 1 (2006), 79 .

15 See Hannu Rautkallio, Suomen juutalaisten aseveljeys [The Comradeship of arms of the Finnish Jews], (Helsinki, 1989).
} 
German allies, too. It was decisive that Finland could not have waged war without Germany.

On the other hand it is equally clear that there had not been the Continuation War of 1941-1944 without the Russian attack and annexations during the Winter War. Finland was very righteously inclined since the oppressive phase of the Russian dominance in Finland at the turn of the century and this was clearly seen in the Finnish attitude in the Winter War. But when the Finns saw how the Soviet Union and other Great Powers could treat smaller nations, they smoothly began to change. When Germany started her offensive against the Soviet Union in June 1941, the Finns followed after a while. Even if the attack was well prepared beforehand, the Russians lost their nerves and first bombarded Helsinki and other Finnish cities and provided Finland with a legal excuse for the war. When the Finnish attack succeeded well, the attitude of the Finns changed further. Despite some doubts they did not stop at the old border. They continued their advance towards Eastern Karelia, in order to get the line of the great lakes easier to defend. Eastern Karelia, which had never directly belonged to Finland, was important as an ethnically related area and one of the cradles of the Finnish culture, too. For example, the Finnish national epic was found in Eastern Karelia. When the German offensives proceeded well, there arose hopes of getting even Eastern Karelia in the peace treaty.

Germany pressed Finland to join politically closer to the Axis powers. Finland was dependent on German armaments and grain. Moreover German armed forces were responsible for the defence of Lapland. Therefore, the Finnish government considered very carefully how far they could go. One possibility was to send volunteers to German international forces. The main stock of the Finnish officers, the Jaegers, had received their military training in the Imperial German army, and the Finns wanted to continue this tradition by joining the Wehrmacht. This was not possible. They had to content with a battalion in the SS-forces like all foreigners. The Finnish battalion fought on the Southern flank of Germany's Eastern front up to Caucasus. When the battalion was repatriated after two years' service in 1943, it was dispersed into different units of the Finnish army. Joining the Anti-Comintern Pact was also estimated possible because Finland already had defended herself against the Communist aggressor in the Winter War. ${ }^{16}$

\footnotetext{
16 See Mauno Jokipii, Panttipataljoona. Suomalaisen SS-pataljoonan historia [Battalion in Pledge. History of the Finish SS-Battalion] (Helsinki 1968).
} 
A separate military administration for the conquered Eastern Karelia was founded. In the hope of annexing the area finally to Finland the Russian minority was gathered to concentration camps, in order to be exchanged to the members of Fenno-Ugrian peoples in Russia after the war. They were no extermination camps, but when the war lasted much longer than expected and there was general lack of food in the country, about a third of the prisoners died of diseases and hunger. ${ }^{17}$ Finland and Germany practiced an exchange of prisoners of war, too. They were exchanged per capita and the Finns were interested to have Finno-Ugrians from the German camps in order to settle them in Eastern Karelia. The Germans correspondingly were interested in the Ukrainians and White Russians who were potentially cooperative but accepted Great Russians, too. There were some 2000 exchanges on both sides. The Finnish interest was derived more from kinship than racism. Some 70 Jewish prisoners-of-camp were delivered to Germans but not because they were Jews but hated political officers of the Red Army. Most Russian prisoners of Jewish origin were kept in Finland up to the end of war. ${ }^{18}$

When Germany could not defeat Russia before the end of the year 1941, Mannerheim started to doubt the victory. ${ }^{19}$ Most Finns still were in euphoria of their victorious battles and the warfare continued without greater offensives. The German disaster of Stalingrad and the allied demand of the unconditional capitulation caused anxiety in 1943. Great Britain had also declared war on Finland at the end of 1941, but it was not followed by military measures. The Finnish Government started to explore the possibilities of peace but it was difficult between the excessive Russian demands and the German opposition. The German occupation of Hungary in the spring of 1944 clearly showed the dangers of separatism. On the other hand the Germans kept continuing their deliveries of arms and grain despite of misgivings. Hitler was content with the letter of President Ryti where he

\footnotetext{
17 Antti Laine, Suur-Suomen kahdet kasvot. Siviiliväestön asema Suomen sotilashallinnossa 19411944 [The two Faces of Greater Finland. The Position of Civilians in the Finnish Military Administration 1941-1944] (Helsinki, 1982).

18 "Heikki Ylikankaan selvitys valtioneuvostolle" [The Account of Heikki Ylikangas to the Finnish Government], Valtioneuvoston kanslian julkaisusarja [The Publication of the Office of the Finnish Government] 5 (2004).

19 Tarkka, 59-60.
} 
vowed that Finland will not make peace under his presidency. ${ }^{20}$ Only after heavy fighting in summer 1944 did the Soviet Union drop her demand of unconditional surrender. It was high time to end the war in order to save the nation. President Ryti resigned and Mannerheim was elected President of Finland. He was free to make armistice.

The armistice was concluded on 19 September 1944. One of the conditions was that the Finns had to repel the German soldiers from Finland. The ending of the long German-Finnish comradeship of arms was not an easy task. The Finnish and German soldiers made an agreement to coordinate the German retreat and the Finnish attack. When the Russians soon discovered the common play, it had to be given up. ${ }^{21}$ Finland's rapprochement to NS-Germany ended in a war between them.

The armistice was at the same time a preliminary peace. Finland got mostly the same kind on peace conditions as after the Winter War. Instead of Cape Hanko the area of Porkkala, nearer to Helsinki, had to be rented as a military base. Finland had to give up the whole Petchenga and pay severe war reparations. In the Continuation war more 60500 Finnish soldiers were killed, altogether 90000 in the Second World War, The Finnish Karelians had again to leave their homes and to be settled in main Finland. ${ }^{22}$ Finland could not attain her grand national design, but the independence and pride of the country were saved. The final peace treaty was signed in Paris on February 10th, 1947 at the same time with the other co-belligerents of Germany.

\footnotetext{
20 See Markku Jokisipilä, Aseveljiä vai liittolaisia? Suomi, Saksan liittosopimusvaatimukset ja RytinRobbentropin sopimus [Comrades of Arms or Allies? Finland, German Demands of Treaty of Alliance and the Ryti-Ribbentrop Agreement] (Helsinki, 2004).

21 Tuomo Polvinen, Between East and West. Finland in International Politics, 1944-1947 (University of Minnesota Press, 1986), 37-54.

22 Martti Häikiö, "Jatkosodan ulkopolitiikka. Pitkospuita rauhaan" [The Foreign Policy of the Copntinuation War. Difficult Path to Peace], Jatkosodan pikkujättiläinen [The Concise History of the Continuation War], Toim/Eds. Jari Leskinen, Antti Juutilainen (Helsinki 2005).
} 


\section{References:}

"Heikki Ylikankaan selvitys valtioneuvostolle" [The Account of Heikki Ylikangas to the Finnish Government], Valtioneuvoston kanslian julkaisusarja [The Publication of the Office of the Finnish Government] 5 (2004).

Häikiö, Martti. "Jatkosodan ulkopolitiikka. Pitkospuita rauhaan" [The Foreign Policy of the Copntinuation War. Difficult Path to Peace], Jatkosodan pikkujättiläinen [The Concise History of the Continuation War]. Toim/Eds. Jari Leskinen, Antti Juutilainen. Helsinki 2005.

Hovi, Kalervo. "Göring ja Talvesõda" [Göring and the Finnish Winter War], Tuna 1 (2006).

Jokipii, Mauno. Jatkosodan synty. Tutkimuksia Saksan ja Suomen sotilaallisesta yhteistyöstä 1940-41 [Emergence of the Continuation War. Researches of the German and Finnish Military Cooperation 1940-41]. Helsinki, 1987.

Jokipii, Mauno. Panttipataljoona. Suomalaisen SS-pataljoonan historia [Battalion in Jokisipilä, Markku. Aseveljiä vai liittolaisia? Suomi, Saksan liittosopimusvaatimukset ja Rytin-Robbentropin sopimus [Comrades of Arms or Allies? Finland, German Demands of Treaty of Alliance and the Ryti-Ribbentrop Agreement]. Helsinki, 2004.

Jussila, Osmo. Terijoen hallitus 1939-1940 [The Terijoki Gióvernment, 19391940]. Helsinki, 1985.

Laaksonen, Lasse. "Kannaksen taistelut" [Combats on the Karelian Isthmus], Talvisodan pikkujättiläinen [Concise History of the Winter War]. Eds. Rari Leslien and Antti Juutilainen. Helsinki 1999, 435-453.

Laine, Antti. Suur-Suomen kahdet kasvot. Siviiliväestön asema Suomen sotilashallinnossa 1941-1944 [The two Faces of Greater Finland. The Position of Civilians in the Finnish Military Administration 19411944]. Helsinki, 1982.

Nevakivi, Jukka. Appeal that was never Made, Allies, Scandinavia and the Finnish Winter War 1939-1940. London, 1976.

Parrtanen, Jukka. Manerheim ja Hitler [Mannerhein and Hitler]. Helsinki, 2012. Peltovuori, Risto O. Saksa ja Suomen talvisota [Germany and the Finnish Winter War]. Helsinki 1985.

Pledge. History of the Finish SS-Battalion]. Helsinki 1968.

Polvinen, Tuomo. Between East and West. Finland in International Politics, 19441947. University of Minnesota Press, 1986.

Rautkallio, Hannu. Suomen juutalaisten aseveljeys [The Comradeship of arms of the Finnish Jews]. Helsinki, 1989.

Tarkka, Jukka. Neither Stalin nor Hitler. Finland during the Second World War. Transl. by David Mitchel. Helsinki, 1991. 
Turtola, Martti. "Katkera rauha ja Suomen ulkopoliittinen asema" [The Bitter Peace and the position of Finnish foreign policy]. In Talvisodan pikkujättiäinen [The Concise History of the Winter War]. Toim/ Eds. Jari Leskinen, Antti Juutilainen. Helsinki, 1999.

Ueberschär, Gerd R. Hitler und Finnland 1939-1941. Die deutsch-finnischen Beziehungen während des Hitler-Stalin-Paktes. Wiesbaden: Frankfurter Historische Abhandlungen 16, 1978.

Ylikangas, Heikki. "Saksa ja Suomi talvisodasta välirauhaan” [Germany and Finland from the Winter war to the Interim peace]. In Heikki Ylikangas, Tulkintani talvisodasta [My interpretation of the Winter War]. Helsinki, 2000. 